\title{
Pastoralist Dilemmas: Where to Go and When to Move, or with Whom to Talk?
}

\author{
Peter Finke ${ }^{1}$ (D)
}

Accepted: 21 August 2021 / Published online: 25 October 2021

(C) The Author(s) 2021

\begin{abstract}
Pastoralists in Western Mongolia face a range of challenges during their annual grazing cycle due to the simultaneous but conflicting needs for secure allocation rules and a high degree of flexibility. In this paper, I analyze the seasonal arrangements and corresponding strategies that households adopt to deal with unpredictable environmental conditions and the demands of supplying livestock with sufficient forage throughout the year. In contrast to game theory simulations, I argue that dilemmas are: a) often not a question of cooperating or not, but form continua of more or less; and b) socially embedded as people operate in a multitude of relationships that influence their decision-making. Therefore, sharing information in a manner that prioritizes the requirements of individual households while not jeopardizing social reputation is crucially important. Rhetorical skills play an important role in this regard, but there are also situations when herders blatantly ignore state law or local institutional arrangements and risk confrontation to ensure the survival of livestock leading to a situation where free-riding may at times become the dominant strategy.
\end{abstract}

Keywords Pastoralism · Information economics · Social reputation · Game theory · Free-riding · Western Mongolia

\section{Introduction}

Dilemmas are a constant feature of human life. Generally, they are situations presenting two options neither of which is unambiguously desirable, either because they entail forfeiting a personal advantage or because they inevitably bring unwanted harm on ourselves or others. The prisoner's dilemma is the best known, referring to situations between either strangers or people who for other reasons are unable or unwilling to exchange information (Axelrod 1984). It describes situations where people must decide to either cooperate or deceive for every encounter, without the choice of responding along the scale of two alternatives. Such situations, however, may not in fact arise frequently in real life.

Anthropologists tend to be hesitant, if not openly hostile, towards game theory models and have rarely used the more mathematical simulations typical for economists or

Peter Finke

peter.finke@uzh.ch

1 Department of Social Anthropology and Cultural Studies, University of Zurich, Andreasstr. 15, Zurich 8050,

Switzerland political scientists. ${ }^{1}$ By contrast, they prefer to observe "natural games" institutionally embedded in broader social frameworks. And while the dilemma simulations help to predict and estimate the options and incentives people have in specific contexts, they tell us less about the social rules and cultural perceptions that guide the decision-making of the actors regarding the choice of strategies. However, pastoralists indeed face dilemmas, including whether and when to sell livestock rather than to increase herd sizes (Perevolotsky, 1986), how to deal with hostile groups or state actors encroaching into their territory (Bollig 2016; Ensminger, 1992; Galaty, 2013), whether to give up their mobile lifestyle and settle (Fratkin, 1997), or how to make use of natural resources without damaging their environment (Ichinkhorloo, 2017).

For this reason, individual households are often not only in competition with each other but also confronted with conflicting interests regarding the balance of short-term and long-term considerations. An exhausted pasture will no longer be available during later seasons, but any loss of animals not only reduces

\footnotetext{
$\overline{1 \text { Exceptions }}$ to this have, most prominently, been explored by Fredrik Barth in his analysis of Pashtun politics in Swat (1959) and Davenport's work among Jamaican fishermen (1960). Also, anthropologists working within a new institutional framework have been more sympathetic towards game theory applications, although few have made extensive use of them (Acheson, 1989; Bollig, 2016; Ensminger, 1992; Finke, 2004).
} 
the annual harvest but also the household's resource endowment and its future fertility (Dahl \& Hjort, 1976; Khazanov, 1984). Therefore, an imminent threat to livestock survival leaves little room for preservation strategies, as these would not benefit a no longer existing herd in the future. It has been shown that therefore local knowledge systems tend to focus on the well-being of herds rather than ecologically sound grazing cycles (Adriansen, 2008; Yeh et al., 2017). In some cases, such scenarios may indeed resemble the threat of a "tragedy of the commons" even though the model and the remedies proposed by Hardin (1968) are certainly far too simple.

I focus on one crucial aspect in the overall scenario. As natural vegetation to feed livestock is a scarce and unreliable resource in the arid regions where pastoralists typically live, access to land and territory has to be organized in complex ways to ensure sufficient grazing as well as flexibility (Casimir, 1992; Dyson-Hudson \& Dyson-Hudson, 1980; Khazanov, 1984). And this implies that it has to be shared in often complicated processes of institutional ambiguity, with trespassing being a ubiquitous possibility. This is as true for Central and Inner Asia although the socialist legacy caused some very distinct patterns to emerge (Bruun, 2006; Finke, 2000, 2004; Humphrey \& Sneath, 1999; Murphy, 2014, 2018; Robinson et al., 2016; Sneath, 2003).

What I discuss is a specific range of dilemmas that apply for herders deciding on when and where to move with their livestock that vary according to season but have some aspects in common. All take place in a social configuration of mostly non-strangers who maintain complex relationships; and they usually allow for decision-making along a continuum ranging from nothing to full cooperation in differing circumstances. Further, these partial or fragmentary cooperative actions are often vital for operating successfully in a complex economic and social setting. While a certain degree of cooperation is necessary, it is not unconditional and too much can be detrimental.

Among the pastoralists of Western Mongolia, decisionmaking is highly individualized, or rather household-based, as is true for many pastoral societies (Finke, 2004; Galaty, 2013; Yeh et al., 2017). ${ }^{2}$ At the same time, decisions often have to be taken ad hoc. Noticing a wolf pack approaching

\footnotetext{
${ }^{2}$ Some authors emphasize the prominence of larger residential units or neighborhoods in Mongolia, most often referred to as neg nutgiynhan, or 'people of one place' (Bazargür et al., 1993; Mearns, 1993, 1996). Others are skeptical about their existence or at least their relevance to organizing collective activities (Müller, 1995; Finke, 2004; Sneath, 2003), and do not consider even the smaller camp, the hotayl, a term seldom used in everyday life, a viable platform. Beyond academic disagreements, this is also important because such imagined communities serve as the basis for governmental and international efforts to create territorially based 'pasture use groups' (PUG), such as the Swiss-funded Green Gold initiative. In most parts of the country, their introduction has met with little enthusiasm among the population for reasons I explain.
}

one's flock or a sudden snowstorm leaves little time to coordinate even with your closest neighbors, not to speak of sharing the last truck available for transporting animals. There are, however, limits to withholding cooperation. In order to maintain reputation people need to cooperate to a degree. And to get information, it is mandatory to also share, so mastery of communicating without revealing too much of one's plans is an important skill. At other times, people act openly (and sometimes aggressively) to the harm of others because they believe they have no other choice. As I show, while such actions are complained about, they do not evoke strong counteraction except in particularly bad years. The scenario in Mongolia certainly differs from other pastoral settings because the state - and inimically-minded neighboring ethnic groups - play less of a role than they do, for example, in East Africa or the Middle East (Fratkin, 1997; Bollig, 2016; Schlee and Watson, 2009). Yet, the underlying idea of the necessity to economize on information sharing and readiness to ignore the interests of others can also be applicable across an extensive range of social situations from agricultural societies, to migration decisions, or in university faculty meetings.

I first describe the methods of data collection and basic outline of the research setting and the changing economic landscape over time. I then present a brief introduction of the general patterns of pastoral mobility over the course of the annual grazing cycle, followed by four sections describing the specific situation in each of the four seasons, starting with winter, which is considered home and is where herders generally spend the most time. I show for each the main dilemmas that evolve out of overlapping or conflicting usage of specific pasture areas in different seasons. Next, I provide an analysis of the situation, focusing on the role of information economics and the threat of a loss of reputation in case of consecutive disregarding of rules. In conclusion, I bring these arguments together and draw some broader implications beyond the empirical case.

\section{Methods and Data Collection}

Research for this paper is based primarily on qualitative methodology. I first visited the region in 1991, just when the transformation from a socialist planned economy to one organized by market principles started. Eight more field trips followed between 1994 and 2018. Research concentrated on one district, Hovd-sum, and within this on one of its constituting sub-units, the third bag, with a population fluctuating between 150 and 200 households over the years. I conducted complete surveys on demographic variables, household economy, and pasture usage during the 1990s, supplemented with smaller samples of usually some dozens 
of households during consecutive stays. These data were complemented with official statistics. ${ }^{3}$

Over the years, I conducted hundreds of semi-structured interviews and casual conversations with herders and nonherders in their homes or on the steppes when grazing flocks on a wide range of topics, with grazing patterns and pasture allocation a major focus. I accompanied local officials and veterinarians counting livestock, vaccinating new-born animals, or settling disputes on pasture allocation, which allowed me to observe debates as they unfolded, escalated, and eventually abated. It also enabled me to draw up seasonal maps of all grazing lands in the bag and their changing population over the years. For situations of conflict and attempts towards their resolution, I used the extended case method to unravel the range of interests and arguments, as well as the courses of action taken by different stakeholders.

\section{Changing Economic Circumstances}

Western Mongolia is distinct from the rest of the country for several reasons. One is its remoteness. To Ulaanbaatar it is a rough, $1,500 \mathrm{~km}$ drive across (until recently) mostly unpaved tracks. ${ }^{4}$ Another peculiarity is climate and landscape, which is dominated by the Mongolian Altay range and the so-called Great Lakes Basin, a huge area of dry steppes and deserts at its northeastern edge. Altitudes range from 1,100 to 4,500 m.a.s.l. Temperatures are cold, with annual means near freezing, and precipitation levels are low, peaking at $300-400 \mathrm{~mm}$ in the upper mountains while much of the lowlands receives $100 \mathrm{~mm}$ or less. Consequently, natural calamities such as droughts, frosts, or snowstorms ( $d z \ddot{u} d)$ occur regularly. The most recent series of dzüd in 1999-2002 and 2009-2010 each killed millions of animals and many families lost everything they had (Ahearn, 2017; Thrift \& Ichinkhorloo, 2015).

The research site, Hovd-sum, has a population of little more than 3,500 individuals, of whom almost $90 \%$ are Qazaqs, the largest national minority, while the rest are Mongols and Uygurs. With a territory of $2,800 \mathrm{~km}^{2}$, this corresponds to a population density of little more than one per $\mathrm{km}^{2}$, close to the average in rural Mongolia. When I began research 30 years ago, the population was almost twice as large, but in the meantime, half the families have migrated to the newly independent state of Qazaqstan, which officially invited its diasporas to join the 'native homeland' (Finke, 2013). This large-scale migration also had major impacts on pastoral management

\footnotetext{
${ }^{3}$ For each year, the local administration generates detailed data on numbers of animals as well as gains and losses. Their accuracy is questionable, and I have been unable to collect full sets over the 30 years, but they enable insight into the fluctuations of individual households and the dynamics of pastoral management (Finke, 2022).

4 At the time of writing, the so-called Millennium Road from Ulaanbaatar to the western provinces has almost been finished and allows much faster transport.
}

and land allocation practices. During the same period, some Mongols moved in but the number permanently relocating never exceeded 50 households. There are also some Qazaq and Mongol herders officially affiliated to other administrative units who utilize pastures in Hovd-sum on a seasonal basis.

Extensive pastoralism has always been the economic basis of the region. During the twentieth century, people were confronted with a series of radical changes, from the establishment of a socialist production and distribution regime to its dismantling and the consequent transformation towards a market-oriented system in the early 1990s. The latter has been accompanied by severe crises and economic downturns, but in recent years, things have gradually improved, and people experienced a modest increase of incomes and living standards. Pastoralism is supplemented with irrigation farming, mainly potatoes, some other vegetables, and melons.. Agriculture is the main economic basis only for a minority of people, but it is an important subsidiary sector. Other economic activities are rare except for trade, which has become a major source of income generation for families selling pastoral and agricultural surpluses as well as for a small group of entrepreneurs. A few families are employed in the local administration as teachers or medical workers, although almost all also own livestock or farm.

Across Central Asia, herders raise sheep, goats, cattle - including yaks -, horses, and a few camels. Since the end of the socialist economy, these are again herded by individual households. Early in the transition period, pastoral strategies focused on risk-reduction, including the increase of herd sizes, a return to multi-species herds, and a retreat to barter and subsistence production. Since then, livestock numbers in Hovd-sum have fluctuated in response to the out-migration of half of the population and the series of $d z \ddot{u} d$ (Fig. 1). But sheep and goat numbers, especially, are fast to recover. Today, the district has close to 200,000 animals, of which more than $90 \%$ are small stock. Goats became more important over recent years for their cashmere, the sole cash crop pastoralists in Mongolia produce for the world market (Finke, 1995, 2004; Murphey, 2018).

Individual herd sizes vary widely, but have on average increased since the early 1990s, first due to the privatization of means of production and later because of their concentration in fewer households because of ongoing migration. Today, there are officially 41 herders with more than 1,000 livestock in the sum. At the other end of the scale are those with fewer than 100, which is considered the minimum herd size needed if there are no other sources of income. Today, this represents only a small minority of herders, and many of these are, in fact, part of larger extended households. Temporary exceptions to this were those periods following a major $d z \ddot{u} d$, as in 2012 and 2013 (Fig. 2).

Across Mongolia, livestock rearing is possible only by means of seasonal mobility due to the short period of plant growth between May and August. Sufficient grazing, therefore, needs to be preserved as standing crops for the rest of 
Fig. 1 Livestock numbers in Hovd-sum 1989-2019
Livestock in Hovd-sum

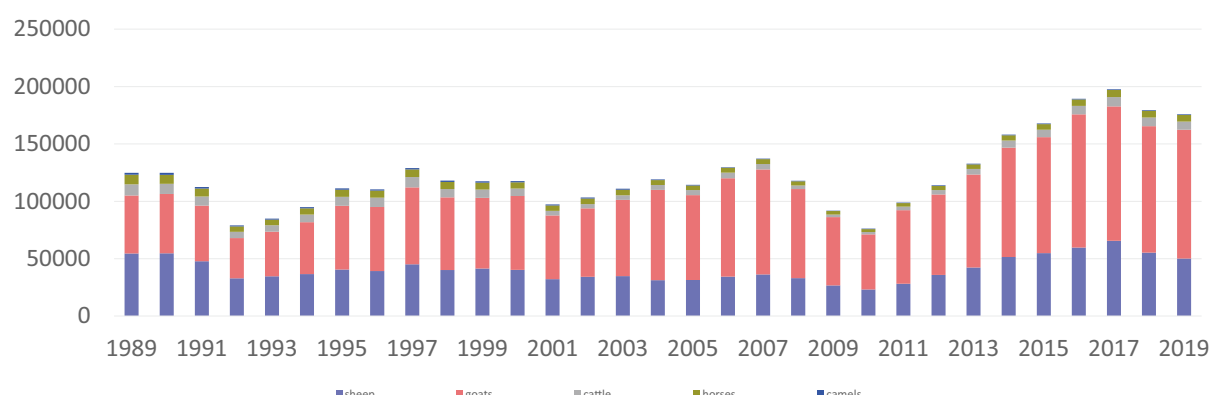

Source: Statistical office of Hovd-sum the year (Fernández-Giménez, 2002). During socialist times, this was controlled by the state. It also supported pastoralists by providing means of transportation, hay supplies, and veterinarian services, as well as regular incomes and pensions, in exchange for set delivery quotas in livestock products and new-born animals (Finke, 2004; Humphrey, 1978). All of this must be organized individually now.

Grazing cycles vary according to herd size and composition as well as available labor. What is specific to the western provinces is that they combine horizontal and vertical movements to make use of altitudinal variations in climate and vegetation, spanning a difference of 1,500+ meters (Nyamdavaa, 1995). Due to inversions in winter, however, the general pattern differs from other mountain regions. There are three basic types of mobility. Most herders, all those who were specialized in small stock during socialist times, have their spring camps in the midlands, at around 1,500 m.a.s.l. (Map 1). They move to the alpine region in summer, migrating to the lowlands during fall before ascending back to the lower mountain valleys for winter since they are warmer and less wind-exposed than the plains and, due to moderate snowfall, provide sufficient water for animal and human consumption. Former large stock herders, by contrast, usually spend three seasons in the plains and visit the alpine region only for summer. Finally, a few yak herders remain in the mountains year around, as this is preferred habitat for their animals (Finke, 2004).

Although people have adapted their annual cycles to the demands of a market economy based on mixed herds, the basic pattern has remained unchanged as it is determined by the winter and spring campsites, which are equipped with permanent facilities for hay storage and animal shelter (hashaa), and often in the possession of the same family for generations. What has changed are the distances involved, as people try to save on transport costs now to be borne privately (Fernández-Giménez, 2002; Müller, 1995). ${ }^{5}$ For that reason, many of the remote mountain pastures had been
Fig. 2 Livestock numbers per household in the third bag 1989 $-2019$

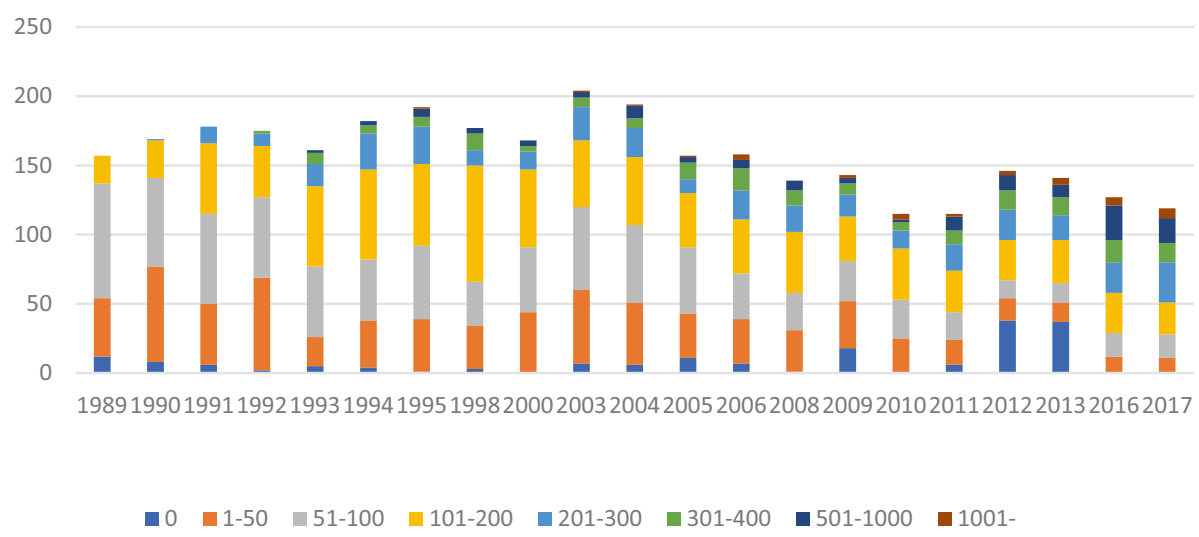

Source: Statistical office of Hovd-sum

$\overline{5}$ The history of land allocation rules in Mongolia has been summarized by Endicott (2012), Fernández-Giménez (1999) and Sneath (2001) although there is a lot of local and regional variation. 


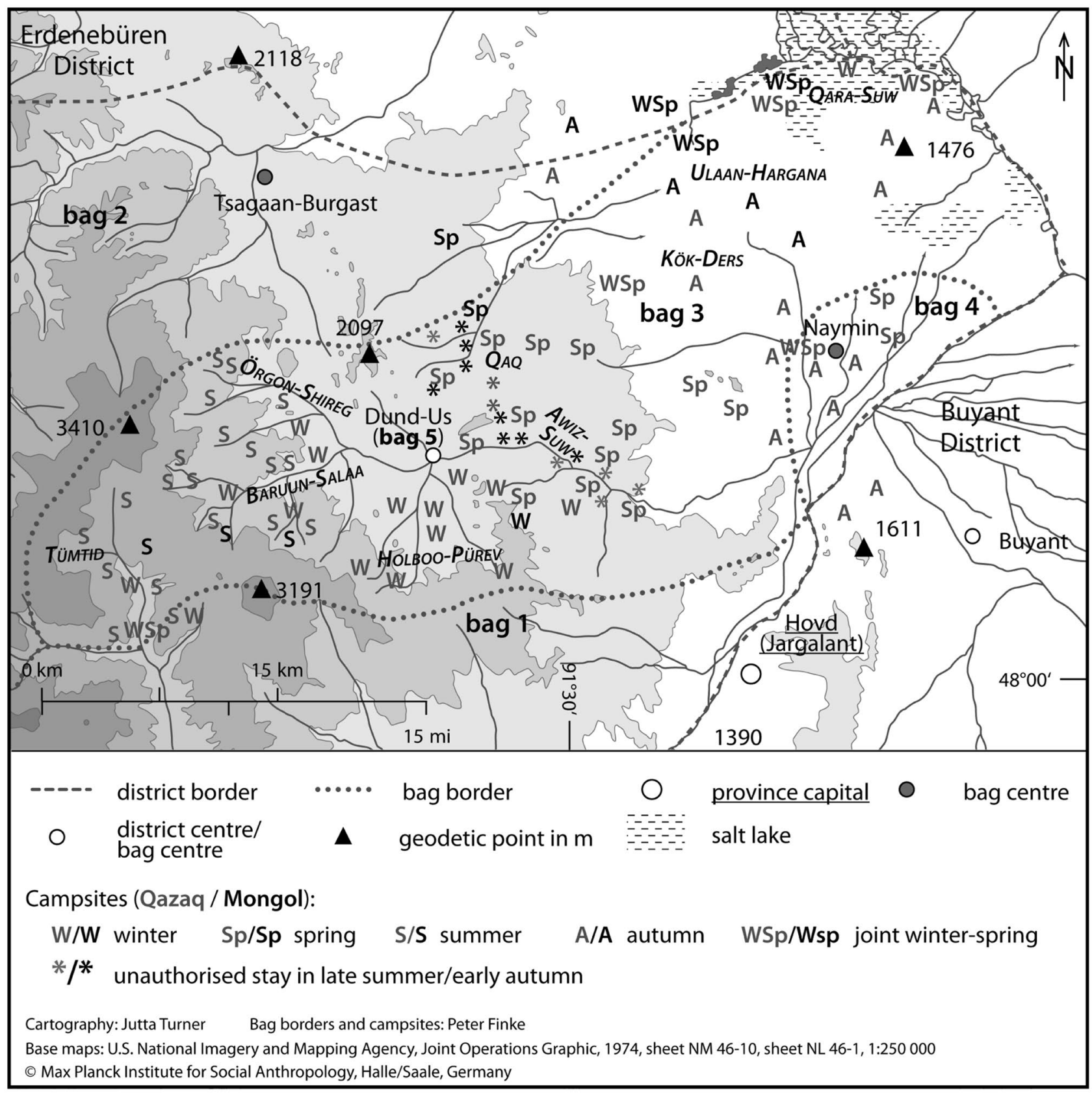

Map 1 Annual cycle in the third bag

virtually abandoned during the 1990s, although now, with growing livestock numbers, they are being utilized again. Other factors that influence pastoral movements are engagement with agriculture, the likelihood of predators or animal theft in specific areas, as well as personal circumstances such as illnesses or upcoming life-cycle ceremonies.

The main challenge here is the location of winter and spring pastures at an intermediate position between the other seasonal sites. To regulate access, the collectives defined specific territories for each season and, most importantly, set the time frames during which they could be utilized. They also determined districts and brigades, the bag of today, as primary grazing boundaries. While not strictly enforced, for the most part herders stay within the respective administrative unit throughout the year. Within each season, herders are in principle free to decide on any given site on a firstcome, first-served basis.

However, established allocation rules are now partly defunct or simply ignored, as is true for many regions in Mongolia. Crossing boundaries happens frequently but is usually not considered a serious issue if it involves the use of pastures during the assigned period of the year. Much more 
threatening is seasonal misuse. There is always a temptation to spend a few days, or weeks, both before and after the summer pasturing in the midlands or the lower alpine zone. This, however, presents hazards to those households settling here during winter or spring. Another source of conflict is a consequence of the re-adjustment of annual cycles to mixed herds, which forces large stock herders to seek additional winter pastures to graze their sheep and goats in the mountain belt in the vicinity of other herders' winter or spring sites.

\section{Seasonal Constraints, Seasonal Considerations}

The following scenarios describe the annual grazing cycles and the corresponding seasonal dilemmas in the third bag, located in the central part of the district. In terms of mobility, it contains all the three patterns of seasonal movement that at times jeopardize each other. The bag is also home to the majority of Mongols in Hovd-sum whose seasonal movements partly follow other criteria. Most spend winter and spring in the lowlands, irrespective of the dominant species in their herds, to stay close together. But in the end every herder has his their own way of coping with seasonal dilemmas.

\section{Winter}

The winter is long and cold in Mongolia, with three months of $-20{ }^{\circ} \mathrm{C}$ and below, and the choice of an appropriate location is of utmost importance. As noted, former sheep and goat herders usually spend it in the mountain region. There are a few families who move into the alpine zone, above 2,000 m.a.s.l., but most stay in the warmer lower lying valleys at 1,600 to $1,800 \mathrm{~m}$.a.s.l. The upper parts of these valleys are often utilized during summer. By contrast, the other half of the bag, those specialised on large stock, spends winter in the bushlands of Ulaan-Hargana, which lie on 1,100 to 1,200 m.a.s.l. and, at this time, are covered by rather high standing grasses rated as less nutritional for small stock and horses. Winter camps in the mountains are occupied in late November with the arrival of snow; those in the plains a month earlier, as they have sufficient water sources nearby.

All winter camps have fixed shelters where hay reserves are stored. Some Qazaq families have a stone or loam house, which retain heat well, but most live in yurts year-round, as do all Mongol herders. Good winter locations are rare because they need to fulfil several criteria, such as the availability of pastures and water, protection against snowstorms, and a certain exposure to the sun. This excludes, for example, open territories or valley grounds as well as slopes facing north (which is also where most winds originate).
Distances between camps are usually five kilometers or more. In the plains, camps are hidden in thick bushes and often hard to find. Households set tents close to each other, as the quantity of forage reserves is greater. Most of the Mongols also have their winter camps in the plains, although some of the rich herders send a family member with small stock to the mountains.

Winter camps are considered more of a home than other seasonal sites. People remain here longer than at other places and rarely change sites in-season. Pasture allocation is thus more or less fixed, and because of the distances and immobility during this part of the year, few disagreements arise. In principle, the surrounding pastures are open to all flocks in reach, that is to say a maximum of five to ten kilometers from their respective campsites. Winter is a time of great scarcity of vegetation and all herders are reliant on the standing crops that have been left, so it is crucial to protect winter pastures during other seasons.

There are two dilemmas people are facing, one of which is about defending one's own campsite and the other about the temptation for encroachment onto other people's spots out of season, namely during summer. The first is due to the precarious nature of winter and the fact that it is spent on intermediate altitudes. The question is whether to stay with a site that offers good pasturing but is also exposed to trespassing in other parts of the year, or to choose one that is less vulnerable, but offers poor grazing. In recent years, some herders have resumed moving to the alpine zone pastures for the cold season, which involves higher costs for fuel and labor, but they are less imperiled by seasonal misuse. Another option is to select a site that is only suitable in winter and thus safe from misuse by others. Most people find it difficult to estimate the costs and benefits involved in any switch of campsites, and changes of winter camps have therefore been an exception.

Another seasonal dilemma is focused on the need of the large stock herders wintering in the plains for a second site to graze their sheep and goats. As they do not have established locations, this is often done on an opportunistic basis. It is mostly young men who are sent off to take care of the small stock of an extended family. To enable commuting, they prefer the lower lying mountain regions, but come into conflict with other herders over trespassing on their winter or spring sites. This is a clear infringement of rules but since many shy away from conflicts this type of trespass has decreased since the mid-1990s, and large stock herders prefer to entrust their small stock to herders who winter in the mountains anyway. This dilemma allows several options for resolution, and the willingness to cooperate, or rather the forgoing of a possible defection, seems to have grown over the years. 


\section{Spring}

In late February, just before the animals give birth, pastoralists wintering in the mountains move down to the dry midlands east of the district center. These are located at altitudes of some 1,400 to $1,600 \mathrm{~m}$ and dominated by feather grass desert-steppes. The midlands are mostly free of snow so animals have easy access to forage. The main water sources now are larger wells that each serve several households. The plateaus are surrounded and interspersed by hills along which most of the camps are situated to avoid wind exposure - crucial at this time year. In the lowlands, most households remain in their winter camps or switch sites only by a few kilometers. As the camps are also near the agricultural fields, many households pursue some supplementary cultivation. Here, the main protection against wind is the hargana bushes (caragana spec.) and, for those who stay near the riverbanks, small trees, and underwood.

Spring is marked by the New Year festivities of tsagaan sar, in the case of Mongols, and nawriz among Qazaqs, and a period of more social exchange. As in winter, all sites are equipped with shelters for animals and hay, and thus allow little flexibility. Densities vary but are generally low due to the general sparsity of vegetation. The most popular spots, such as Qaq or Awiz-Suw, each accommodate a dozen or more households within an area of approximately $50 \mathrm{~km}^{2}$. Other sites are less densely populated. However, water sources quickly deplete and since plant growth starts only in early May, for most of the season animals have to subsist on the previous year's vegetation. In late May and early June, some herders move up the mountains for an intermediate stop towards their summer pastures.

Campsites are static during the first part of spring due to the location of built facilities. Critical is the use of spring pastures during other parts of the year, and herders' ability to monitor and protect the pastures from overexploitation by outsiders is important. A problem with a second move in spring is that it requires a new site, usually near winter pasture belonging to other herders who can control trespassing only when they make the same move, thus putting additional pressure on their own pastures. But even in this case they do not necessarily have a means to make the transgressors leave, creating situations where tolerance is lowest and the potential for violence highest, as grazing on other people's spring pastures is, in a bad year, equivalent to destroying their livelihood.

The dilemmas in spring campsites are thus like those in winter. One is again defensive, namely that favorable places are equally attractive for other herders in other seasons. A transgression of pasture areas is particularly threatening at this time of the year because animals are at their weakest and about to give birth to the next generation. Some try to solve this by occupying their own camps during fall to ensure that at least the immediate surroundings will not be trespassed upon. Suspiciously eyeing each other, they at the same time encroach on the larger grazing area to the detriment of all (cf. Fernández-Giménez, 2002). But the situation is more complex than a collective action dilemma because some households may have sent a portion of their livestock to be herded by other households. Thus, the dilemma allows for many potential partial solutions or degrees of cooperation.

The other dilemma is whether to make a second move later in the season, and if so, where to go. Such a move requires access to resources. It also causes resentment among herders who have their winter pastures at spots in the lower lying mountain areas popular during May and June. At the same time, many of the transgressors argue that their move in the first place is because of insufficient protection of their own spring pastures the year before. As with the winter dilemma, such movements have become less frequent than in the 1990s and are no longer considered a major problem. People now prefer to stay at one campsite, and when necessary, send parts of their herds to better located households.

\section{Summer}

With the rise of temperatures in the second half of June, herders leave the mid- and lowlands to move uphill. The designated summer sites are in the high mountain zones of upper Baruun-Salaa and its tributaries, all above $1,800 \mathrm{~m}$, which in turn lead to what many consider the ultimate destination, the high plateau valley of Tümtid, at 2,200 to 2,500 m.a.s.l. Depending on temperatures and vegetation, herders may make an earlier stop in lower Baruun-Salaa, or Örgön-Shireg, a popular summer pasture area west of the district center. Located at 1,700-1,800 m.a.s.l., these are slightly lower but some households will stay here for the whole season as it is closer to the settlements and access to the market or irrigated fields is easier. However, those with larger herds usually leave after few weeks, as the grass is regarded as of lower quality than that of the high-altitude pastures.

Summer is considered a period of abundance, fresh air and the lush meadows of the mountain steppes that allow animals to quickly gain weight. Criteria for a good site also differ from other seasons. Wind exposure is now considered a positive asset, as it dispels the summer heat. Water can be a problem and some alpine valleys lack permanent sources during summer. Households stay for about six to eight weeks in their summer camps, depending on annual rainfall and vegetation. During this time, some will change sites, which is a matter of much consideration. Towards the end of the season, the question is whether to move back to ÖrgönShireg or to the spring areas Qaq and Awiz-Suw, which in the second half of August become crowded again. In exceptional years, they may also stay longer in the mountains and move directly to their fall camp. Any additional move 
involves costs, both for transport and in terms of weight loss for the animals. But these may be easily exceeded by other advantages, or rather the prevention of misfortunes. For example, an early snowstorm in the mountains, which can happen anytime during the second half of August, may cause death among small stock.

Access rules also differ. As there are no hashaa the herders are much more flexible and many switch sites within, as well as over the years. There is some idea of customary rights to specific places if these have been used for many years, but there is no way to enforce them. If people stay within the designated seasonal areas, the allocation is effectively one of first-come, first served. The seasonal influx of pastoralists from neighboring districts has not changed this yet, and if they leave on time they are not considered a threat. Tensions are rare during summer. It is a time of hard work, with cattle, horses, and some small stock milked, and of frequent mutual visiting. Cooperation is probably most intensive, also because people settle closer to one another. But summer is also a period of careful observation of the weather and the environment, and of other peoples' management decisions. When travelling through the district, I was constantly asked how the grass looks in different places, who is currently settling there, and whether those families came with or without large stock. In fact, a prime objective of the frequent visits among men during summer - usually entailing the offer of qimiz, fermented mare's milk, a favorite of Qazaqs and Mongols - is exchange of information on pasture conditions and planned movements.

The summer dilemmas are thus of a different kind. Any move within the season requires weighing costs and labor against the promise of better pasturage to allow animals to gain maximum weight to survive the upcoming winter. Herders thus try to gain as much additional information as they can from other households without revealing too much of their own intentions. Should many households come to the same solutions, those that implement them earlier will access the most desirable pastures, while late-comers may end up having to settle on the fringes or make an additional move, investing more money and labor as well as stressing their livestock. To avoid such situations, herders are reluctant to disclose their intentions. I would frequently meet people a few weeks after I had interviewed them at a very different site than the one they had described to me.

A second dilemma arises when herders decide to stay outside the designated summer pasturage, such as in lower Baruun-Salaa, to save on transport costs and for easier access to the market. This may lead to tensions with pastoralists having their winter camps here, although they rarely become serious. One way to deal with this is again by occupying a site close to one's own winter camp to protect it from trespassers. As noted earlier, this strategy can contribute to the depletion of grass in the surrounding areas, although some who adopt it leave the bulk of their herd further up with a son or brother. Again, this is not so much an either-or question of cooperation but one of degree. And it represents a classic collective action problem where everyone would be better off when cooperating, but worst in case of a unilateral move to do so. All herders would benefit when pastures are used only within a season, but it is not a good idea to be the only one to do so because it encourages others to graze livestock without control.

\section{Fall}

The situation in fall, again, differs, although it resembles summer more than other seasons. The final destination is usually fixed, but movements in-between are not. Most herders spend the period from September to November near the agricultural fields along the lower Buyant River where they also collect hay. Others settle scattered throughout the neighboring desert-steppes or along the banks of the Hovd River, all between 1,100 and 1,300 m.a.s.l. Those wintering in the plains already spend fall in the vicinity of their hashaa. At this time of the year, the pastures here are particularly valuable as they contain salt, which helps the animals increase their fat reserves for winter.

People are rather flexible on where to settle in fall because there are few variables to decide among and differences between potential sites are minor. Everywhere there is sufficient water from open streams and small wells. Similarly, vegetation is plentiful, although not of the highest nutritional value. Temperatures are warm and winds are rare. An issue to consider is that grazing livestock poses a threat to crops that are not yet harvested, and their owners will be heavily fined if detected. To avoid disputes many herders leave their large stock in the mountains and bring only sheep and goats.

Access rules are equally flexible but early fall is also a period of permanent alert and constant negotiations. During the second half of August temperatures begin to decline and the first snow falls in the mountains. At the same time, the lowlands remain rather warm but are plagued by swarms of mosquitoes. Herders must wait for them to disappear or risk their livestock stampeding. This is a most serious matter and I witnessed families losing up to one third of their animals that had run away and fallen prey to wolves or theft. Therefore, people wait for as long as necessary in the midlands, at the risk of punishment for staying near the spring camps of other herders. Local chiefs from time to time try to persuade people to move on who in turn argue that this would endanger the survival of their herds.

One dilemma in fall is again the question of whether to make additional moves. Information on local conditions remains important but is less an issue of knowledge on vegetation. The possible places to go are all very obvious and the only variable is when the mosquitoes disappear. As in 
summer, what people had told me (and others) often did not reflect what they later did. Some of this may be intentional deception, but more often plans change due to ambiguous circumstances or updated information. Another decision is whether to move to the lowlands with all animals or have large stock stay in the mountains with little supervision. Theft of large stock, which happens mostly in the plains, is regarded as a bigger challenge than wolves, and encroachment of cattle or horses onto agricultural fields is a matter of concern.

Early fall is by far the most conflict-prone season, and the dilemma is now one of cooperation per se. It is during this time that pastoralists most bluntly ignore the needs of others. Everyone is aware that a longer stay in Qaq or AwizSuw will lead to consumption of pastures of those herders who have no other option but to return here in spring. But herders' calculations are focused on the demands of their own animals. This could only be solved by a strong district administration enforcing a rule that is, however, nowhere written down in detail. Most herders show little concern about threats from the authorities. Even those who had signed papers indicating their willingness to move within a fixed period openly acknowledged that it would not influence their decision to stay. Less resembling a prisoner's dilemma, it is one of unequal power. Those willing to encroach on others' territories tend to do so rather confrontationally without much compromise, risking a possible fine, while those whose pastures are consumed have little power to prevent it.

\section{Information Economics and Social Reputation}

This last dilemma points to a very crucial moment in this scenario. It is not that pastoralists in Mongolia, or anywhere else in the world, do not care about the well-being of their peers. But when it comes to the critical periods of livestock management there is too much at stake to allow for many concessions. If pastures around a spring camp were used up in the previous fall, the herd will be lost and thus the future of a household threatened. On the other hand, to forgo an intermediate stay in the midlands and to expose the herd to the mosquito infestation may be equally disastrous. Availability of sufficient pastures during the cold seasons is essential to ensure herd survival, particularly of new-born livestock in the spring. This is less of a problem in favorable weather conditions and fewer conflicts will arise in a good year. But after a season of poor plant growth, when temptation to graze herds on others' territories is high, many reported that they lost one third or more of their animals. It is not surprising that spring campsites are the most fiercely protected.

It is important to emphasize the general unpredictability associated with most pastoral economies that cannot be avoided. There is nothing herders can do about that, except seeking supplementary sources of income or leaving the pastoral sector altogether. These may be temporary strategies, but once a herd is depleted it is difficult to rebuild it again. In a more immediate way than for other production systems, pastoralism can be described as a "game against nature" (Davenport, 1960). People can adopt strategies to mitigate adverse conditions, but, ultimately, they have no control over the climate. So, in addition it is also a game against each other as they compete for suitable pastures.

Information is the most crucial resource, both about climate, for which improvements in weather forecasting and communication technologies make a huge difference, as well as the plans of other herders. Whenever they are able, herders gather as much information as possible on vegetation and the presence or absence of other households, but also on the seriousness of sanctions and threats by the local authorities. If representatives appear in a camp, they are offered tea, food and, if believed to be helpful, alcoholic beverages as a means of appeasement and conciliation. If herders conclude a particular spot is a good choice, they do not want too many others to reach the same idea and thus increase competition for access. Otherwise, it is not a good plan anymore. But this also means that everyone is cautious when it comes to evaluating others' observations for, they may always contain a certain amount of deception.

Careful balancing of information seeking and spreading also necessitates specific skills, which are not equally distributed. The goal is firstly to acquire as much and as accurate information as possible. Visiting among herders is one way to do so. Mobile phones are becoming an additional means of communication, but the information provided is even more difficult to check. Others have the advantage of settling along a major route so that many will stop by for entertainment or having a rest. This, however, usually entails their pastures being used for transition routes. It is difficult to assess whether people are more willing or feel morally obliged to share information when they receive rather than offer hospitality, but it would seem very likely. It seemed to me that hosts tended to adopt a more demanding tone in conversation than guests when it came to inquiries on pasture.

Seeking information is one part of the game. Concealing it is the other one, and it is equally a question of skills. People cannot simply refuse to answer, and herders are judged according to their trustworthiness when it comes to information shared. From observation, I would argue that probably the more difficult skill is seeming to provide more information than is in fact communicated. To be able to sustain a conversation without revealing too much or being too obviously vague is an art in itself. Upcoming events, such as a wedding, the latest horse race, or the affairs of relatives in 
Qazaqstan are popular themes for digressing. Another element of the game is the use of a wide array of arguments for why one should stay or cannot move to a particular place, no matter how dubious they may sound (Finke, 2022).

Two important aspects of pastoralist dilemmas stand out. One is that decisions are rarely a question of yes or no, but especially for the sharing of information, rather more a continuum. The other issue is that actors are linked with each other in multiple ways. The only exception to this is those who have migrated from the city to the countryside after the end of socialism and a relatively small number of herders who come to the district for seasonal grazing. Even these families usually have relationships with at least some others or have developed them over time. For everyone else, the people one quarrels with will be either kin, friends, or, at least, seasonal neighbors. This social embeddedness also invokes another issue, namely that relationships are to some degree reciprocal. While it is not that trespassing is an equal threat to everyone, transgressors may have other exchange relations not to be jeopardized.

Inequalities in vulnerability come from a range of variables, including herd size and composition, labor availability, and ethnicity. Other things being equal, rich herders have a greater interest in the protection of pastures because they need larger territories for grazing and more resources should they have to resettle. And, most important, not everyone's grazing areas are equally in need of seasonal protection. This gives an advantage for the former larger stock herders, among them most of the Mongols, who do not have to worry about a misuse of their winter or spring camps in the lowlands, which are of little use during any other time of the year. But they are particularly in need for a second site for their sheep and goats in winter. For that reason, Mongol herders tend to be perpetrators rather than victims. At the same time, many of them need Qazaq partners to trade hay or agricultural products with.

Herders also differ in their standing and popularity within the community as well as in their openness to flexibility. Some advocate strongly that each year circumstances differ and one must respond to the specific conditions in any given season. Others prefer to move to the same places each year, justifying this with the preference of animals for habitats they are used to. For the latter, neither information seeking nor concealing is as crucial - although they still suffer encroachment on their seasonal pasture areas. For most Mongols, this is also an issue of legitimacy. Advocating a regime of open access, many of them question the right of a Qazaq-dominated administration to impose restrictive rules on them as the national majority. The fact that the district authorities are usually more hesitant to place sanctions on Mongol pastoralists clearly shows that they have a point in that, if not morally then in practice. This unequal bargaining position is exacerbated by the large-scale migration to
Qazaqstan and the continuing option to do so (Finke, 2022). As relative newcomers who have been moving in and out of the country, the legitimacy of Qazaq claims is limited, to say the least. It is further constrained by the general lack of enforcement due to the incapacity of the authorities to implement effective legislation (Fernández-Giménez \& Batbuyan, 2004; Undargaa, 2016, 2017; Upton, 2008, 2012).

The situation is exacerbated by the lack of institutional support with a state apparatus that is no longer willing or capable of enforcing land allocation rules and punishing trespassers. This may be considered a positive development because it allows the needed flexibility in pastoral management but at the same time potentially threatens social cohesion and sustainable use of natural resources. Self-governance does not seem a feasible option, a possible legacy of the socialist period when all disputes and conflicts were addressed by the state (Fernández-Giménez, 1999; Finke, 2004; Ichinkhorloo, 2017). But neighbors or kin are not asked for support in case of a conflict either. If people take matters into their own hands, it is, therefore, on an individual basis. Equally, the idea to establish territorial lease groups has not been met with much enthusiasm by the pastoralists concerned. So far, although officially state property, herders move around freely and do not pay any taxes or rents on pastureland. ${ }^{6}$

As the situation is similar for all, misconduct usually does not lead to informal sanctions either. Even a constant disregard of protected campsites will not cause ostracization. This may well happen to people who are considered greedy or aggressive in other situations of social conduct. But in the case of pasture transgression, the situation seems comprehensible, even for those affected badly. It could happen to everyone else in a comparable situation. This does not make people less angry should they suffer livestock losses as a result of pasture damage. And in bad years, it may provoke violent action. But it does not push people out of the community because it is, to some degree, considered part of the game. And, so far, the wish to maintain overall peaceful relations is quite strong across ethnic boundaries.

\section{Conclusion}

I present a series of scenarios for pastoral households in Western Mongolia during the course of an annual grazing cycle that I term, in reference to game theory simulations, pastoral dilemmas, although they admittedly describe very different situations. What they all have in common is that households must decide on strategies that either forfeit their own advantage or put potential harm in the way of

\footnotetext{
${ }^{6}$ NGOs do not yet play a role in the region. The same is true for grass-roots organizations, called horshoo in Mongolia.
} 
others. Furthermore, and the actual dilemma, to make reasonable decisions pastoralists must seek as much information as possible while at the same time attempting to withhold from others. This is driven by the fact that one's own decisions will prove futile should too many others reach the same conclusions.

I propose these dilemmas are "real life" situations. On the one hand, it refers to the fact that many of the situations are not addressed by a yes or no to cooperation but by responses at varying degrees along a continuum. On the other hand, all decisions made and actions pursued are part of social life in general. Pastoralists are firmly embedded into the local community and maintain intensive relationships with one another. Although this limits the probability of confrontation and misconduct it does not stop people from doing things that they would not like others to do to them. As I stated earlier, one reason is that too much is at stake to allow for many concessions. When people see the survival of their herds jeopardized, they show little concern in occupying pastures that they know are crucial for others in later seasons. At the same time, this is a reason why comparatively little is done to prevent them from doing so. Others would eventually act in very much the same way. And in an average year the damage done may not be worth the conflict arising out of confrontation.

A second reason is that decision-making is highly individualized. This also means that neither transgressor nor victim can rely on a strong group of kin or allies that would support them should they take matters in their own hands. And it is also the individual herders who collect and accumulate information on vegetation and the mobility of other households to be able to evaluate alternatives as accurately as possible. But the need to gather information also demands a willingness to share to some degree, as otherwise people would not be inclined to do the same. In other words, any conversation on pastures takes the form of an exchange where each side will try to gain and retain an advantage, a kind of negative reciprocity (Sahlins, 1972).

I believe that this is a general pattern that we may find in other settings. Obviously, the specific situations of what is at stake and how people interrelate differ. Also, the character of the means of production, in this case livestock and pastures, and the demands and constraints of actors vary. The story also goes beyond the fact that information is always scarce and usually asymmetrically distributed, as transaction cost theories rightly propose (Ensminger, 1992; North, 1990). Here, to make one's own decisions feasible one has to mis- or under-inform others. A most obvious parallel that comes to mind is the bazaar economy as described by Geertz (1978). But I suspect the same pattern when people exchange information to make decisions to migrate or on the distribution of departmental resources in a university. After all, most of our encounters do not take the form of a simple yes or no on cooperation decisions, but a careful balancing of the extent and form of cooperation, and we adapt our strategies on information seeking and concealment accordingly.

Funding Open Access funding provided by Universität Zürich. My early work in the 1990s was funded by studentships from the Free University Berlin and the German Academic Exchange Service (DAAD). Later research periods were supported as part of employment by the Max Planck Institute for Social Anthropology, Halle, Germany, and the University of Zurich, Switzerland.

\section{Declarations}

Ethics Approval Research was conducted in line with the ethical standards established by the American Anthropological Association and the Swiss Anthropological Association.

Conflict of Interest The author declares that he has no conflict of interest.

Informed Consent Participation in the study was voluntary and anonymous. Informed consent was obtained from all individual participants included in the study. The data and personal information collected through this study were treated confidentially.

Open Access This article is licensed under a Creative Commons Attribution 4.0 International License, which permits use, sharing, adaptation, distribution and reproduction in any medium or format, as long as you give appropriate credit to the original author(s) and the source, provide a link to the Creative Commons licence, and indicate if changes were made. The images or other third party material in this article are included in the article's Creative Commons licence, unless indicated otherwise in a credit line to the material. If material is not included in the article's Creative Commons licence and your intended use is not permitted by statutory regulation or exceeds the permitted use, you will need to obtain permission directly from the copyright holder. To view a copy of this licence, visit http://creativecommons.org/licenses/by/4.0/.

\section{References}

Acheson, J. M. (1989). Management of Common-Property Resources. In S. Plattner (Ed.), Economic Anthropology (pp. 351-378). Stanford University Press.

Adriansen, H. K. (2008). Understanding Pastoral Mobility: The Case of Senegalese Fulani. Geographical Journal, 174, 207-222.

Ahearn, A. (2017). Herders and hazards: covariate dzud risk and the cost of risk management strategies in a Mongolian subdistrict. Natural Hazards: 1-17.

Axelrod, R. (1984). The Evolution of Cooperation. Basic Books.

Barth, F. (1959). Segmentary Opposition and the Theory of Games: A Study of Pathan Organization. Journal of the Royal Anthropological Insitute, 89, 5-21.

Bazargür, D., Shiirevadja, C., Chinbat, B. (1993). Territorial Organisation of Mongolian Livestock Husbandry in the Transition to a Market Economy (Policy Alternatives for Livestock Development in Mongolia (PALD), Research Report No. 1). Brighton, 
Ulaanbaatar: Institute of Development Studies, Institute of Agricultural Economics.

Bollig, M. (2016). Towards an Arid Eden? Boundary-making, governance and benefit-sharing and the political ecology of the new commons of Kunene Region, Northern Namibia. International Journal of the Commons, 10(2), 771-799.

Bruun, O. (2006). Precious Steppe: Mongolian Nomadic Pastoralists in Pursuit of the Market. Lexington Books.

Casimir, M. J. (1992). The Determinants of Rights to Pasture: Territorial Organisation and Ecological Constraints. In M. J. Casimir \& A. Rao (Eds.), Mobility and Territoriality: Social and Spatial Boundaries among Foragers, Fishers, Pastoralists and Peripatetics (pp. 153-204). St. Martin's Press.

Dahl, G., Hjort, A. (1976). Having herds: Pastoral herd growth and household economy. Stockholm Studies in Social Anthropology, Stockholm.

Davenport, W. (1960). Jamaican Fishing: A Game Theory Analysis. Yale University Publications in Anthropology, 59, 3-11.

Dyson-Hudson, R., \& Dyson-Hudson, N. (1980). Nomadic Pastoralism. Annual Review of Anthropology, 9, 15-61.

Endicott, E. (2012). A History of Land Use in Mongolia: The Thirteenth Century to the Present. Palgrave Macmillan.

Ensminger, J. (1992). Making a Market: The Institutional Transformation of an African Society. Cambridge University Press, Cambridge, New York.

Fernández-Giménez, M. E. (1999). Sustaining the Steppes: A Geographical History of Pastoral Land Use in Mongolia. Geographical Review, 89(3), 315-342.

Fernández-Giménez, M. E. (2002). Spatial and Social Boundaries and the Paradox of Pastoral Land Tenure: A Case Study from Postsocialist Mongolia. Human Ecology, 30(1), 49-78.

Fernández-Giménez, M. E., \& Batbuyan, B. (2004). Law and Disorder: Local Implementation of Mongolia's Land Law. Development and Change, 35(1), 141-166.

Finke, P. (1995). Kazak Pastoralists in Western Mongolia. Economic and Social Change in the Course of Privatization. Nomadic Peoples 36/37: 195-216.

Finke, P. (2000). Changing Property Rights Systems in Western Mongolia: Private Herd Ownership and Communal Land Tenure in Bargaining Perspective. Working Papers No. 3, Max Planck Institute for Social Anthropology, Halle/Saale.

Finke, P. (2004). Nomaden im Transformationsprozess: Kasachen in der post-sozialistischen Mongolei. Lit-Verlag.

Finke, P. (2013). Historical Homelands and Transnational Ties: The Case of the Kazak Oralman. Zeitschrift Für Ethnologie, 138(2), $175-194$.

Finke, P. (2022). Pastoral Ways of Life. Economic Diversification and Social Stratification among Qazaqs in Western Mongolia. Routledge, London, New York.

Fratkin, E. (1997). Pastoralism: Governance and Development Issues. Annual Review of Anthropology, 26, 235-261.

Galaty, J. (2013). Land grabbing in the Eastern African rangelands. In A. Catley, J. Lind, \& I. Scoones (Eds.), Pastoralism and development in Africa: Dynamic change at the margins Pages (pp. 143-153). Routledge.

Geertz, C. (1978). The Bazaar Economy: Information and Searchin Peasant Marketing. American Economic Review, 68, 28-32.

Hardin, G. (1968). Tragedy of the Commons. Science, 162(3859), 1243-1248.

Humphrey, C. (1978). Pastoral Nomadism in Mongolia. The Role of Herdsmen's Cooperatives in the National Economy. Development and Change 9(1): 133-160.

Humphrey, C., \& Sneath, D. A. (1999). The End of Nomadism? Society, State, and the Environment in Inner Asia. Duke University Press.

Ichinkhorloo, B. (2017). Environment as Commodity and Shield: Reshaping Herders' Collective Identity in Mongolia. In A.
Ahearn, T. Sternberg, \& A. Hahn (Eds.), Pastoralist Livelihoods in Asian Drylands: Environment, Governance and Risk (pp. 41-70). The White Horse Press.

Khazanov, A. M. (1984). Nomads and the Outside World. Cambridge University Press.

Mearns, R. (1993). Territoriality and Land Tenure among Mongolian Pastoralists: Variation, Continuity and Change. Nomadic Peoples, $33,73-103$.

Mearns, R. (1996). Community, collective action and common grazing: The case of post-socialist Mongolia. Journal of Development Studies, 32, 297-339.

Müller, F.-V. (1995). New Nomads and Old Customs: General Effects of Privatisation in Rural Mongolia. Nomadic Peoples, 36(37), 175-194.

Murphy, D. J. (2014). Ecology of Rule: Territorial Assemblages and Environmental Governance in Rural Mongolia. Anthropological Quarterly, 87(3), 759-792.

Murphy, D. J. (2018). Disaster, Mobility, and the Moral Economy of Exchange in Mongolian Pastoralism. Nomadic Peoples, 22(2), 304-329.

North, D. C. (1990). Institutions Institutional Change and Eonomic Performance. Cambridge University Press, Cambridge.

Nyamdavaa, G. (1995). Altayn uularxag nutgiyn mal azh axuyn gazarzüyn asuudald: Xovd aymgiyn zhisheen deer [Geographical aspects of pastoralism in the Altay mountatin region: The example of Hovd province]. Academy of Sciences, Ulaanbaatar.

Perevolotsky, A. (1986). To sell or not to sell-A Pastoralist's Dilemma: A lesson from the slaughterhouse. Human Ecology, 14(3), 287-310

Robinson, S., Kerven, C., Behnke, R., Kushenov, K., \& MilnerGulland, E. J. (2016). Pastoralists as Optimal Foragers? Reoccupation and Site Selection in the Deserts of Post-Soviet Kazakhstan. Human Ecology, 45, 5-21.

Sahlins, M. (1972). Stone Age Economics. Chicago: Aldine-Atherton.

Schlee, G., Elizabeth E. W. (eds.). (2009). Changing identifications and alliances in North-East Africa (2 volumes). London, York: Berghahn.

Sneath, D. A. (2001). Notions of Rights over Land and the History of Mongolian Pastoralism. Inner Asia, 3(1), 41-58.

Sneath, D. A. (2003). Landuse, the Environment and Development in Post-socialist Mongolia. Oxford Development Studies, 31(4), 441-459.

Thrift, E.D., and Ichinkhorloo, B. (2015). Management of dzud Risk in Mongolia: Mutual Aid and Institutional Interventions. In FernándezGiménez, M.E., Baival, B., Fassnacht, S.R., and Wilson, D. (eds.), Building Resilience of Mongolian Rangelands: A Trans-disciplinary Research Conference. Nutag Action and Research Institute, Ulaanbaatar, pp. 136-141.

Undargaa, S. (2016). Pastoralism and Common Pool Resources: Rangeland Co-management, Property Rights and Access in Mongolia. Routledge, London.

Undargaa, S. (2017). Re-Imagining Collective Action Institutions: Pastoralism in Mongolia. Human Ecology, 45(2), 221-234.

Upton, C. (2008). Social Capital, Collective Action and Group Formation: Developmental Trajectories in Post-socialist Mongolia. Human Ecology, 36(2), 175-188.

Upton, C. (2012). Managing Mongolia's Commons: Land Reforms, Social Contexts, and Institutional Change. Society \& Natural Resources, 25(2), 156-175.

Yeh, E., Samberg, L. H., Gaerrang, V., \& E., and Harris, R.B. . (2017). Pastoralist Decision-Making on the Tibetan Plateau. Human Ecology, 45(3), 333-343.

Publisher's Note Springer Nature remains neutral with regard to jurisdictional claims in published maps and institutional affiliations. 